\title{
CARDIOGEL SUPPORTS ADHESION, PROLIFERATION AND DIFFERENTIATION OF STEM CELLS WITH INCREASED OXIDATIVE STRESS PROTECTION
}

\author{
P. Sreejit and R.S. Verma* \\ Stem Cell and Molecular Biology Laboratory, Department of Biotechnology, \\ Indian Institute of Technology Madras, Chennai-600036, TN, India
}

\begin{abstract}
Cultured murine bone marrow derived mesenchymal stem cells (BMSC) when grown along with cardiogel derived from mouse cardiac fibroblast, exhibited increased cell proliferation and differentiation and enhanced survival under oxidative stress induced by the exposure of $\mathrm{H}_{2} \mathrm{O}_{2}$ in vitro (similar to in vivo ischemia like condition). Adhesion of BMSC to the cardiogel occurred at a faster rate when compared to the cells grown on normal surface. BMSC attached to cardiogel showed an increased resistance to proteolytic (enzymatic) disassociation. This is the first report on an attempt to use an in house biomaterial for the growth of BMSC that led to their heightened resistance towards oxidative stress. These studies support that cardiogel is an efficient biodegradable three-dimensional extracellular matrix which supports better growth of BMSC and can be used as a scaffold for stem cell delivery, with potential therapeutic applications in cardiac tissue regeneration.
\end{abstract}

Key Words: Stem cells, proliferation, differentiation, cardiogel, oxidative stress protection, therapeutic biomaterial.

*Address for correspondence:

Rama Shanker Verma

Stem Cell \& Molecular Biology Laboratory

201, Bhupat and Jyoti Mehta School of Biosciences,

Department of Biotechnology, Indian Institute of Technology Madras,

Chennai - 600036 TN, India

Telephone numbers: +91-44-22574109; 22575109

E-mail: vermars@iitm.ac.in
Introduction

It is well known that progression of myocardial infarction gradually leads to heart failure (Struthers, 2005). Current heart failure treatment is largely focused on maintaining the residual overburdened cardiomyocytes (Christman and Lee, 2006; Chen et al., 2008; Abbate et al., 2009). Recently, cell therapy has emerged for the treatment for several heart diseases (Costanzo et al., 1995; Heng et al., 2004; van Laake et al., 2006; Zhu et al., 2009). Cell therapy is based on the principle of supplementing the insufficient inherent repair mechanisms within diseased heart by utilizing either embryonic and/or adult stem cells besides mesenchymal stem cells, hematopoietic stem cells, umbilical cord blood cells and skeletal satellite myoblasts (Orlic et al., 2002; Reffelmann and Kloner, 2003; Dimarakis et al., 2005; Bettiol et al., 2007; Tang and Phillips, 2007; Catharina et al., 2008).

Undifferentiated stem cells can differentiate into multiple lineages after transplantation (Jon et al., 2001; Donald and Darwin, 2007). Transplantation of stem/ progenitor cells into damaged cardiac muscles has been known to induce differentiation into scar tissue containing fibroblasts (Wang et al., 2001). Under such circumstances, very few transplanted stem cells differentiate into cardiomyocytes, thereby reducing the clinical efficacy of stem cell transplantation therapy for myocardial regeneration and finally affecting the revival of heart function after myocardial infarction. Microenvironment/ niches, the environment in which stem cells are found, can interact to regulate stem cell fate, direct noncommitted stem cells towards specific lineages and play a role in proliferation (Dimarakis et al., 2006a; Dimarakis et al., 2006b). It has been shown that transplanted human embryonic stem cells (hESC) precommitted to cardiomyogenic lineage by prior co-culture with END2 cells (mouse endoderm-like cell line), can survive, integrate, mature and proliferate after intramyocardial injection in immunodeficient mice (van Laake et al., 2008).

However, stem cell transplantation in cardiac therapy by means of the direct injection method is subject to the loss of intercellular communication, extracellular matrix (ECM), and cell numbers. But its efficacy can be improved by the use of patches of synthetic composites or biomaterials as carrier (Ishii et al., 2005; Piao et al., 2007). In ischemic heart, these materials enhance the binding of injected cells to the substratum at or near the site of injury (ischemia) without disrupting the cell-cell microenvironment and prevent their loss by extrusion (Memon et al., 2005; Christman and Lee, 2006; Chen et al., 2008). Attempts have been made to replace infarcted 
cardiac tissue with tissue-engineered cardiac patches made of biocompatible and bioabsorbable materials like purified ECM molecules and heterogeneous mixtures of ECM components (Heng et al., 2004). Co-delivery of cells with various matrices including collagen matrices, Gel Foam and Matrigel has been successfully carried out (Kutschka et al., 2006; Laflamme et al., 2007). But their long term effects, including immunogenic response in most cases have not been studied well.

Cardiogel is a naturally occurring extra cellular matrix derived from in vitro cultured fibroblasts. It is composed of laminin, fibronectin, and interstitial collagens (Types I and III) besides other proteins, proteoglycans, and growth factors (VanWinkle et al., 1996). ECM components considerably influence the growth characteristics of cardiomyocytes, development of physiological activities such as spontaneous contractile activity and phenotype morphological differentiation, suggesting synergestic effect of ECM components (Bick et al., 1998; Song et al., 2007). Elementary cardiac differentiation mechanisms have been elucidated using animal models along with in vitro models of cardiac development such as mouse embryonal carcinoma cells, mouse embryonic stem cells and recently, human embryonic stem cells (Kraehenbuehl et al., 2008; Beqqali et al., 2009). The growth rate and adhesion of murine mesenchymal stem cells in cardiogel were found to increase when co-cultured together (Chang et al., 2007).

In coronary diseases, narrowing of heart arteries result in ischemia where there is a decreased blood and oxygen supply to heart, which can ultimately lead to a heart attack. Reactive oxygen species (ROS), a major cause of injury after ischemia/reperfusion, may hinder the adhesion and spreading of MSCs (Angelos et al., 2006; Song et al., 2010). Tissue hypoxia mediates an increase in the ROS burst at reperfusion and is associated with further impairment of LV functional recovery. Efficacy of stem cell therapy using cardiogel in ischemic conditions has not been well studied. In the present study, we have cultured bone marrow derived stem cells isolated from adult mice along with cardiogel and report the survival of stem cells against oxidative stress, which can occur during reperfusion of ischemic areas of heart. The proliferative potential of the bone marrow derived stem cells growing on cardiogel as well as the adhesion capability of stem cells was also evaluated.

\section{Materials and Methods}

\section{Isolation and culture of bone marrow derived mesenchymal stem Cells (BMSC)}

6-8 week-old Swiss albino mice were procured from Tamil Nadu Veterinary and Animal Sciences University, Chennai. All procedures, approved by the Institutional Animal Ethics Committee (IIT Madras, India) and the Committee for the Purpose of Control and Supervision of Experiments on Animals, Government of India, were performed under the Rule 5(a) of the Breeding and Experiments on Animals (Control and Supervision) Rules (1998). All the animals used for the experiments were killed by cervical dislocation. Bone marrow-derived mesenchymal stem cells (BMSC) were collected from the aspirates of the femurs and tibias of mice $(\sim 20 \mathrm{~g})$ with $10 \mathrm{ml}$ of BMSC maintenance medium (BMM) consisting of DMEM/F12 ( $1: 1)$ medium (Invitrogen, Carlsbad, CA, USA) supplemented with fetal calf serum (FCS) (20\%) (Gibco; Invitrogen), penicillin (100 U/ml), and streptomycin (100 $\mathrm{mg} / \mathrm{ml}$; Invitrogen), $2 \mathrm{mM}$ L-glutamine (Invitrogen), 0.1 $\mathrm{mM}$ nonessential amino acids (Invitrogen) and $3 \mathrm{mM}$ sodium pyruvate (Invitrogen). Cells were washed twice and resuspended in BMM and plated at a density of $1 \times$ $10^{4}$ cells per $\mathrm{cm}^{2}$ in flasks. Cultures were maintained at $37^{\circ} \mathrm{C}$ in a humidified atmosphere containing $5 \% \mathrm{CO}_{2}$. After $72 \mathrm{~h}$, non-adherent cells were discarded, and the adherent cells were thoroughly washed twice with Dulbecco's Phosphate Buffered Saline (DPBS). Fresh complete medium was added and replaced every 3 or 4 days for $\sim 10$ days. The cells were harvested after incubation with $0.25 \%$ trypsin and $1 \mathrm{mM}$ EDTA (Invitrogen) for $5 \mathrm{~min}$ at $37^{\circ} \mathrm{C}$ and re-plated at densities of $5 \times 10^{3}$ cells per $\mathrm{cm}^{2}$. These cells were maintained for further studies and in most experiments cells between Passage Number (Pn) 5 and Pn 12 were used. For experiments, plates coated with cardiogel and controls precoated with $0.2 \%$ gelatin were used. The isolated cells were characterized by immunocytochemical analysis using antibodies for the surface markers CD29, CD34, CD45, (Santa Cruz Biotechnology, Santa Cruz, CA, USA), CD106 and Sca-1 (BioLegend, San Diego, CA, USA) with 1:100 dilution for primary antibodies and 1:200 dilution for fluorophore conjugated secondary antibodies (Sigma-Aldrich, St. Louis, MO, USA) as described earlier (Chang et al., 2007).

\section{Preparation of Cardiogel matrix coated plates}

Cardiogel was prepared from confluent cardiac fibroblasts in-house using a modified version of a previously described protocol (Song et al., 2007). Briefly, the fibroblasts were isolated by differential attachment of digested mouse cardiac tissue suspension as described earlier (Sreejit et al., 2008). Whole hearts of 6-8 week-old Swiss albino mice killed by cervical dislocation, were excised and immediately transferred into ice cold DPBS. Excised hearts were washed with chilled PBS, followed by sterile icecold balanced salt solution (20 mM HEPES-NaOH $(\mathrm{pH}$ 7.6), $130 \mathrm{mM} \mathrm{NaCl}, 1 \mathrm{mM} \mathrm{NaH} \mathrm{PO}_{4}, 4 \mathrm{mM}$ glucose, 3 $\mathrm{mM} \mathrm{KCl}$ ), in which the tissue was kept for $10 \mathrm{~min}$. The tissues were then minced with a sterile scalpel blade into small pieces $\leq 1 \mathrm{~mm}^{3}$ in $0.05 \%$ trypsin EDTA (Invitrogen) $(0.3 \mathrm{ml}$ per heart $)$ and transferred into sterile $15 \mathrm{ml}$ falcon tubes. The myocardial cells were dispersed by incubating with $0.5 \%$ Trypsin EDTA ( $\sim \mathrm{ml}$ of Trypsin for every 100 mg of tissue) and were then mixed by intermittent pipetting along with stirring at $37^{\circ} \mathrm{C}$ in a water bath for $4 \mathrm{~min}$. The cell suspension was allowed to stand for $1 \mathrm{~min}$. The supernatant containing single cells was collected into 15 $\mathrm{ml}$ falcon tube kept on ice, to which $2 \mathrm{ml} \mathrm{DMEM/F12}$ (1:1) medium (Invitrogen) supplemented with $20 \%$ fetal calf serum (Invitrogen) was added and the digestion step was repeated thrice. The cell suspensions from each digestion were pooled and centrifuged at $2500 \mathrm{~g}$ for 10 $\min$ at $4^{\circ} \mathrm{C}$. 
The cell pellet was resuspended in a Cardiac Maintenance Medium (CMM) containing DMEM/F12 (1:1) medium supplemented with fetal calf serum $(20 \%)$, horse serum (Invitrogen) $(5 \%)$, penicillin $(100 \mathrm{U} / \mathrm{ml})$ and streptomycin (100 mg/ml) (Invitrogen), 2mM L-glutamine (Invitrogen), $0.1 \mathrm{mM}$ non essential amino acids (Invitrogen), $3 \mathrm{mM}$ sodium pyruvate (Invitrogen) and bovine insulin $(1 \mu \mathrm{g} / \mathrm{ml})$ (USV, Mumbai, India). Viability of cardiomyocytes was assessed by the Trypan blue exclusion test. The cells were plated on plates pre-coated with $1 \%$ gelatin and incubated in $95 \%$ air and $5 \% \mathrm{CO}_{2}$ at $37^{\circ} \mathrm{C}$ for $\sim 2-3 \mathrm{~h}$, to allow the differential attachment of cardiac fibroblasts. The non-adherent cells were removed and the plates were washed twice with DPBS. The adherent cells were maintained in CMM. On attaining confluency, the adherent cardiac fibroblasts were trypsinized and replated at a density of $1 \times 10^{4}$ cells per $\mathrm{cm}^{2}$ into plates precoated with $0.2 \%$ gelatin. When these cells reached confluency, (3-4 days), the medium was carefully aspirated and the plates were rinsed gently with PBS.

$1 \mathrm{ml}$ of pre-warmed extraction buffer $(0.5 \%$ Triton X$100,20 \mathrm{mM} \mathrm{NH}_{4} \mathrm{OH}$ in DPBS) was added to the plate, and the process of cell lysis was observed using an inverted microscope (Nikon Eclipse TS100, Melville, NY, USA), until no intact cells were visible (20-60 s). The cellular debris were washed off with chilled DPBS and the plates were stored at $37^{\circ} \mathrm{C}$ in DPBS.

Control plates and dishes were coated with $0.2 \%$ gelatin dissolved in water. Gelatin suspension was added to the wells and coated by exposing it to ultraviolet (UV) rays of $\sim 62 \mu \mathrm{W} / \mathrm{cm}^{2}$ intensity for $20 \mathrm{~min}$ to enhance cross-linking. The coated plates were incubated at $37^{\circ} \mathrm{C}$ for $2 \mathrm{~h}$ after removal of excess gelatin suspension and used for further experiments.

\section{Proliferation assay}

To determine the rate of cell proliferation (fold increase) of BMSC in cardiogel, BMSC were seeded on $0.2 \%$ gelatin coated (control) and cardiogel coated plates at an initial density of $\sim 5 \times 10^{3}$ cells per $\mathrm{cm}^{2}$. Cells were incubated for 12 days at $37^{\circ} \mathrm{C}$ in a humidified $5 \% \mathrm{CO}_{2}$ incubator. Cell growth at different time points $\left(6^{\text {th }}, 9^{\text {th }}\right.$ and $12^{\text {th }}$ day $)$ was estimated by the MTT (3-(4,5-Dimethylthiazol-2-yl)-2,5diphenyltetrazolium bromide) assay. The above protocol was done in conjunction with CFU-F assay, both of which were modifications of the protocols described earlier (Lapi et al., 2008).

\section{MTT assay}

Cell viability of the plated cells in cardiogel was measured by the MTT assay (Song et al., 2007). The MTT assay was used for cell proliferation studies as it measures the cellular activity of mitochondrial dehydrogenases. The optical density of the formazan product formed was measured. The MTT assay was also used for understanding the effects of stress in cells, since stress can influence the number of viable cells. Similarly in adhesion studies, the number of viable adherent cells in the wells remaining after the studies was estimated using the amount of MTTformazan produced during the assay. Normal growth medium was used as blank and appropriate cell controls for each assay were also kept for validating the obtained data. The experiments were performed thrice in duplicates.

\section{Colony forming unit-fibroblast (CFU-F) assay}

The MSC proliferative induction capability of cardiogel was evaluated by CFU-F analysis. Bone marrow cells (passage number 2, 7 and 9) were seeded into the plates at an initial density of $\sim 5 \times 10^{3}$ cells per $\mathrm{cm}^{2}$ in BMM. Cells were incubated for 14 days at $37^{\circ} \mathrm{C}$ in a humidified $5 \%$ $\mathrm{CO}_{2}$ incubator. The medium was changed twice per week. On day 13 , cultures were simultaneously fixed and stained with $0.1 \%$ crystal violet in $20 \%$ methanol by incubating them at room temperature for $30 \mathrm{~min}$, and then washed twice with PBS. Crystal violet stained fibroblastic colonies with more than 50 cells were counted, to rule out colony formation due to aggregation, and then photographed (Nikon Eclipse Ti). The experiment was performed in triplicate.

\section{Stress induction studies}

BMSC (initial inoculation of $\sim 5 \times 10^{3}$ cells per $\mathrm{cm}^{2}$ ) were grown on control and cardiogel coated plates. Cells $(\sim 60 \%$ confluency) were treated with various concentrations of hydrogen peroxide $\left(\mathrm{H}_{2} \mathrm{O}_{2}\right)$ (Merck, Darmstadt, Germany) in maintenance media for various time periods. $\mathrm{H}_{2} \mathrm{O}_{2}$ was diluted in Milli-Q water from the stock solution. Media was replenished and diluted $\mathrm{H}_{2} \mathrm{O}_{2}$ of various concentrations was added into the well to obtain final concentrations of $50 \mu \mathrm{M}, 500 \mu \mathrm{M}, 5 \mathrm{mM}$ and $50 \mathrm{mM}$. After $\mathrm{H}_{2} \mathrm{O}_{2}$ addition, cells were incubated in dark at $37^{\circ} \mathrm{C}$ in a humidified atmosphere containing $5 \% \mathrm{CO}_{2}$ for 1 to 4 days. After the required exposure, the treatment media was decanted and fresh media was added. The MTT assay was carried out to determine the cell growth and survival.

\section{Cell adhesion studies}

To determine whether cell proliferation on cardiogel was an outcome of cellular attachment to the scaffold, cellular adhesion assays were performed. The adhesion potential of BMSC in cardiogel within a short time period was assessed using a modified version of a previously described protocol (Vohra et al., 2008). BMSC were seeded onto cardiogel containing plates in concentrations ranging from $10^{3}$ to $10^{4}$ cells per well of a 6 well plate and allowed to adhere for $1 \mathrm{~h}$ at $37^{\circ} \mathrm{C}$. Following $1 \mathrm{~h}$ adhesion, wells containing cells were washed thrice with DPBS to remove non-adherent cells. The adherent cells were visualized and photographed under an inverted microscope with attached camera (Nikon Eclipse Ti). The cell adhesion index was quantified by the MTT assay.

To determine the intensity of cellular adhesion of BMSC to cardiogel, which is reliant on the time required by the cells to disassociate from the surface, the following protocol was developed.

BMSC were also seeded on cardiogel containing plates and allowed to grow. After attaining $\sim 70 \%$ confluency, the wells were washed with DPBS and then trypsinized with $0.25 \%$ Trypsin (Invitrogen) for varying time periods. The wells were exposed to trypsin for $0.5,1$ and $5 \mathrm{~min}$ 


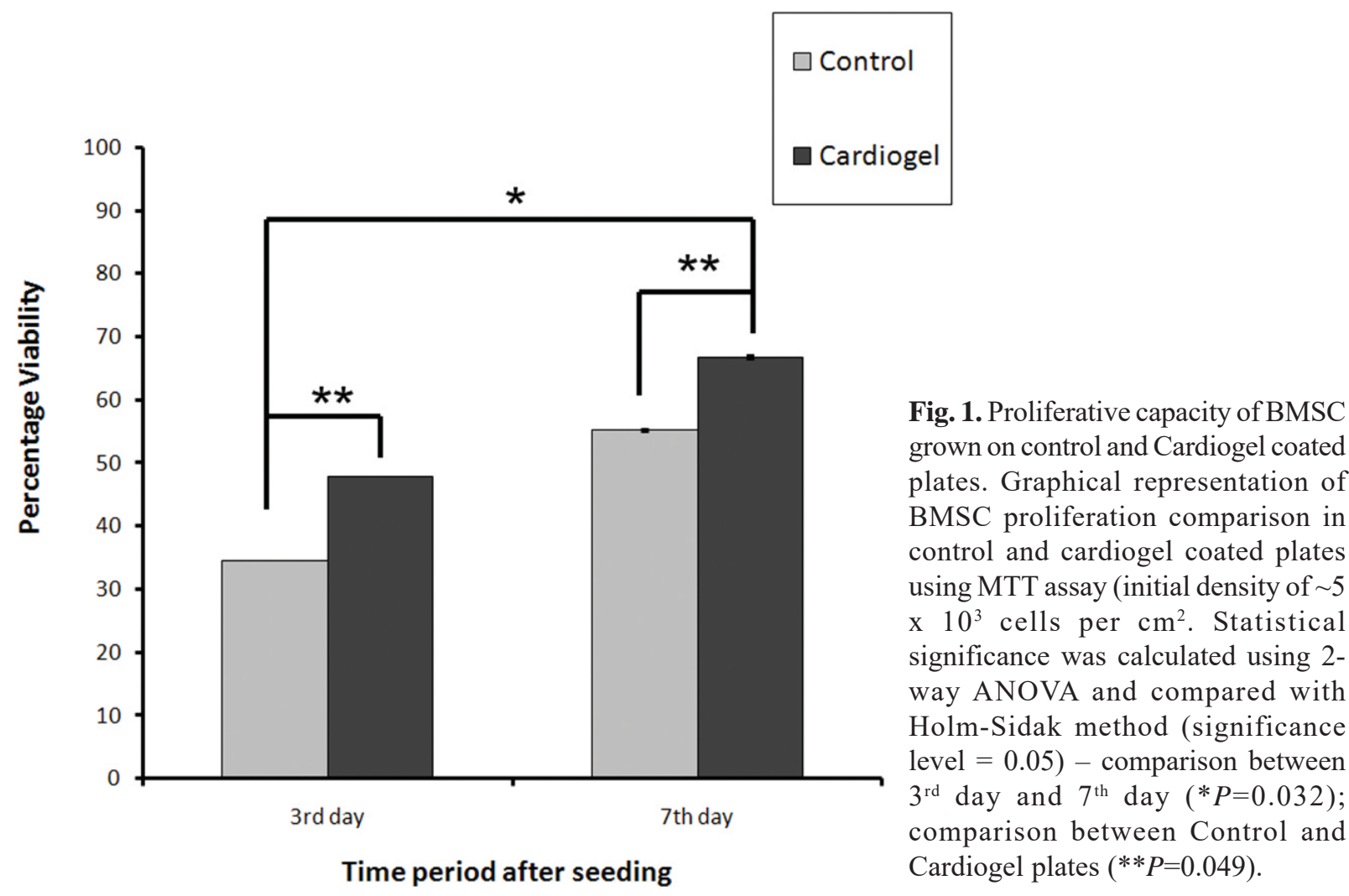

before neutralization with media containing $20 \% \mathrm{FCS}$. The wells were washed thrice with DPBS to remove nonadherent cells. The adherent cells were visualized and images recorded as described earlier. The cell adhesion index was again measured by the MTT assay.

\section{Scanning electron microscopy}

BMSC were seeded on glass cover slips coated with cardiogel and allowed to grow. After attaining 70\% confluency, the cover slips were chemically fixed with $2.5 \%$ glutaraldehyde at room temperature and then serially dehydrated in ethanol. The surface of the cover slip was sputter coated in a vacuum with an electrically conductive $5 \mathrm{~nm}$ thick layer of Gold/Palladium alloy using a Precision Etching Coating system (Gatan, Warrendale, PA, USA; Model 682). Scanning electron microscopy (SEM) images were then recorded with a High Resolution SEM (FEI, Hillsboro, OR, USA; Quanta 200).

\section{Statistical analysis}

Statistical analysis was performed by analysis of variance (ANOVA) and the Holm-Sidak test using the Sigma Plot version 10 software package on the data obtained from the MTT assays conducted during cell proliferation studies, CFU-F assay and Stress Induction studies. $P$-values of $\leq 0.05$ indicate significant differences.

\section{Results}

\section{Isolation and characteristics of BMSC}

BMSC were isolated from mixed cultures based on their attachment on the culture plate. Isolated BMSC grew in patches of long and slender cells, resembling the characteristic morphology of bone marrow derived mesenchymal stem cells. Initial passages showed the presence of cell types with various other morphological features. Most of these cells were macrophages, dendritic cells or other non stem cell populations found in the bone marrow (Inaba et al., 1992). With the increase in passage number, gradual decline in non stem cells was observed. An increase in number of differentiated/progenitor cells were also observed simultaneously. Hence in our study, cells of Pn 4 and above were used. When the isolated bone marrow derived stem cells were characterized by immunocytochemical analysis with antibodies against the following markers: CD 29 (+ve); CD 106 (weak +ve); Sca - 1 (weak +ve); CD 45 (- ve); CD 34 (- ve), it was found that the cells obtained after Pn 2 were mostly Mesenchymal Stem Cells (MSCs) (data not shown).

\section{Proliferation assay and CFU-F assay}

The proliferation rate of BMSC was found to be higher in cardiogel-coated plates than in normal plates $(0.2 \%$ gelatin coated). Initially, noteworthy variations between the expansion rates of BMSC grown in normal and cardiogel were observed (one week). Two-Way ANOVA showed statistically significant difference between the mean of BMSC proliferation values $(P=0.032)$ among the different days (Day 3 and 7) after allowing for effects of differences in surfaces (Cardiogel coated and Control). Similarly, statistically significant difference between the mean of BMSC proliferation values $(P=0.049)$ among the different surfaces (Cardiogel coated and Control) was greater than would be expected after allowing the effects of differences in days (Day 3 and 7) (Fig. 1). However, after 10 days the difference gradually subsided as the cells were approaching confluency (data not shown). 

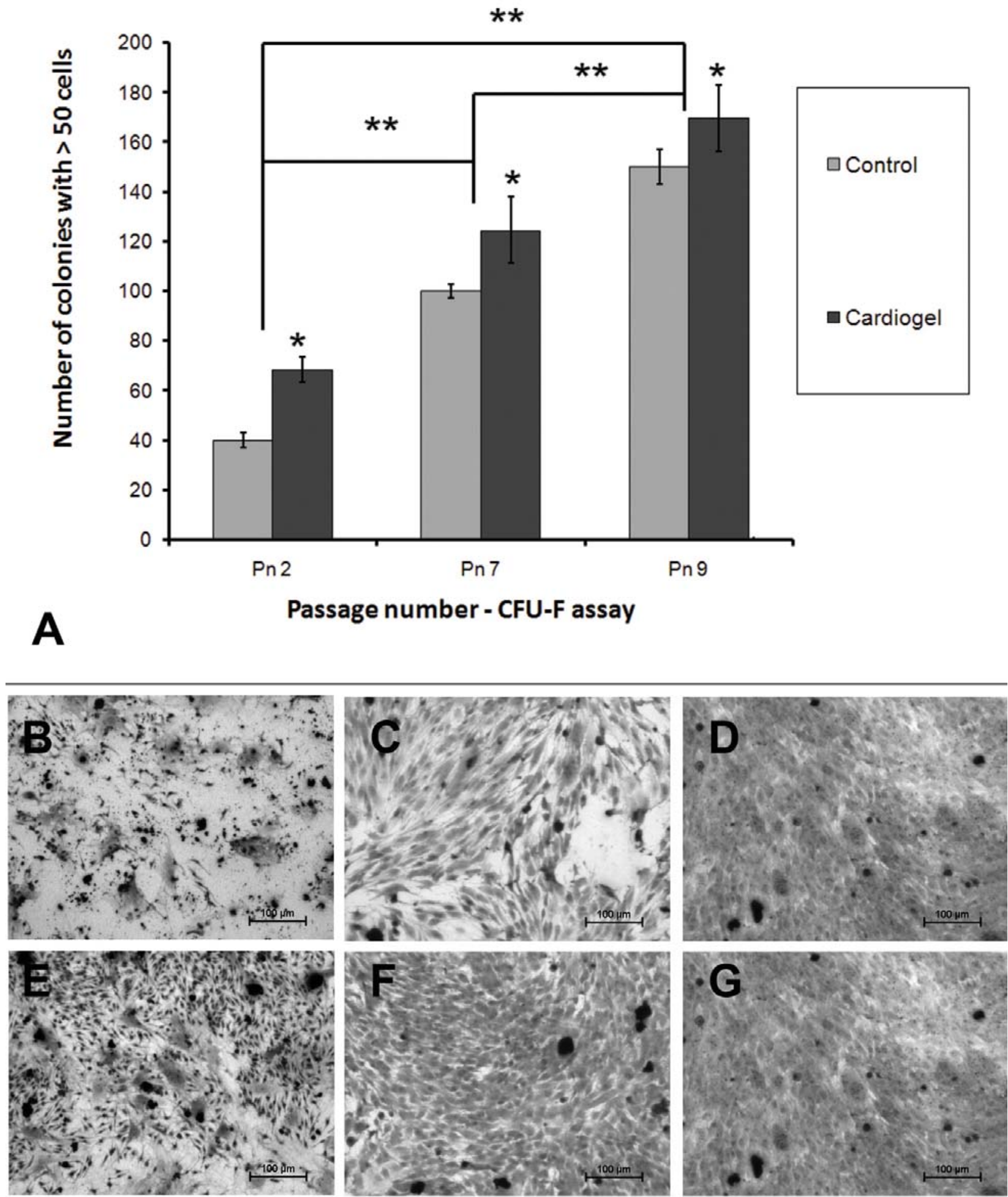

Fig. 2. CFU-F assay. (a) Graphical representation of the comparison of CFU-F colonies growing on control and cardiogel coated plates from different passages of BMSC (BMSC - initial density of $\sim 5 \times 10^{3}$ cells per $\mathrm{cm}^{2}$ ). Statistical significance was calculated using 2-way ANOVA and compared with Holm-Sidak method (significance level $=0.05)-$ comparison between $\operatorname{Pn} 2$, $\operatorname{Pn} 7$ and $\operatorname{Pn} 9(* * P=<0.001)$; comparison between Control and Cardiogel $(* P=0.002)$; (b,c,d) Images of BMSC (Passage number 2,7 and 9 respectively) grown on control $(0.2 \%$ Gelatin coated) plate showing scale bar of $100 \mu \mathrm{m}$ size; (e,f,g) Images of BMSC (Passage number 2, 7 and 9 respectively) grown on cardiogel coated plates showing scale bar of $100 \mu \mathrm{m}$ size. 


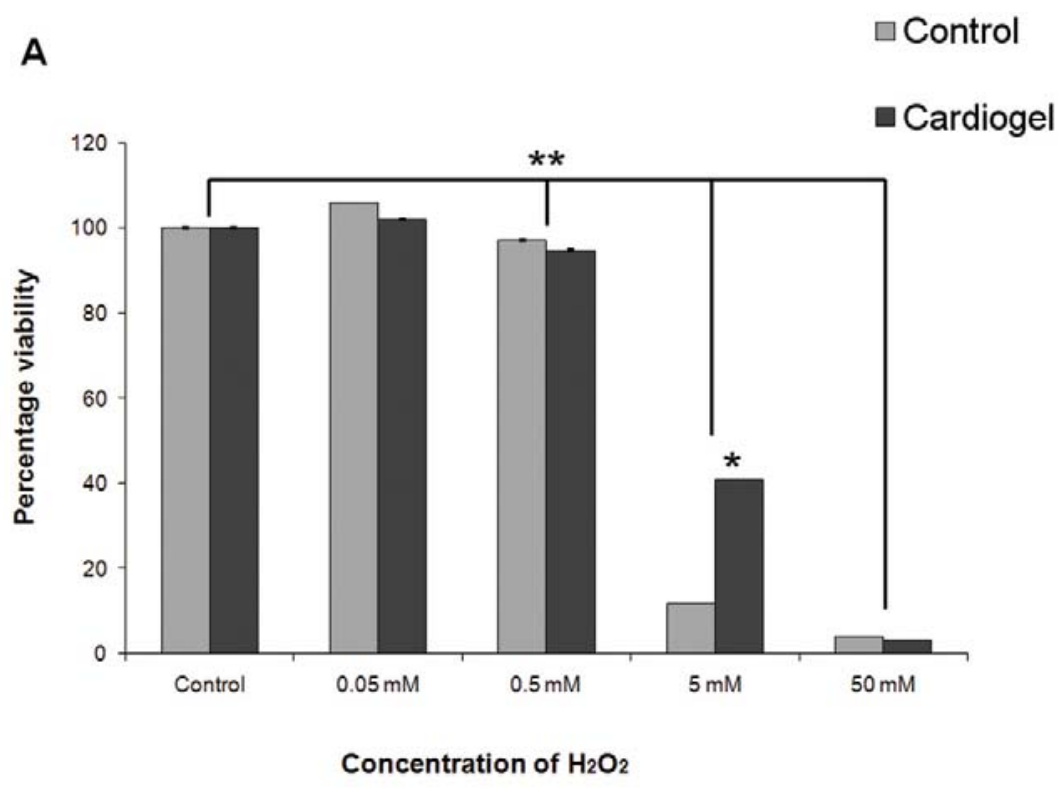

\section{B}

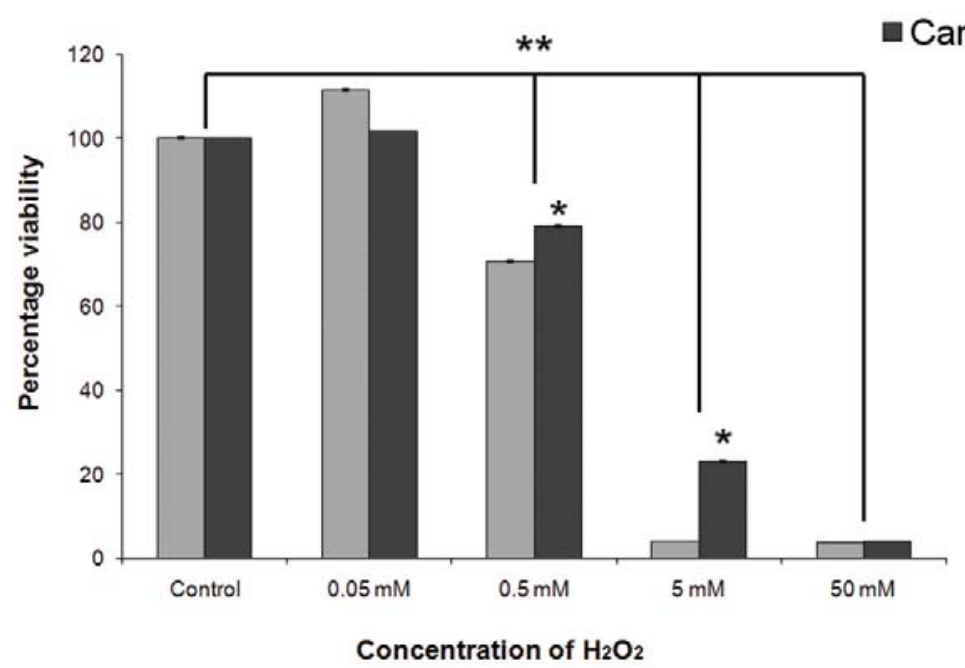

Fig. 3. Cell Viability assay of BMSC after oxidative stress induction. Cell viability assay of BMSC in Control and Cardiogel coated Plates (post $\mathrm{H}_{2} \mathrm{O}_{2}$ treatment), with percentage viability calculated by considering OD values of untreated wells as $100 \%$. Statistical significance was calculated using 3-way ANOVA and compared with Holm-Sidak method ( significance level $=0.05)-$ comparison between 4 day and 1 day $\mathrm{H}_{2} \mathrm{O}_{2}$ exposure $(P=0.026)$; comparison between $\mathrm{H}_{2} \mathrm{O}_{2}$ concentration $0,0.5,5$ and $50 \mathrm{mM}$ (**P $=<0.001)$; comparison between Control and Cardiogel $\left({ }^{*} P=0.047\right)$. (a) After 1 day $\mathrm{H}_{2} \mathrm{O}_{2}$ treatment ; (b) After 4 day $\mathrm{H}_{2} \mathrm{O}_{2}$ treatment.
The proliferative induction capability of cardiogel in BMSC to CFU-F was determined. To assess the increase in number of cells, MTT assay was performed to estimate the number of viable cells. Low density seeding $\left(\sim 5 \times 10^{3}\right.$ cells per $\mathrm{cm}^{2}$ ) was performed to attain optimal results and to rule out any deviation, cells were plated simultaneously and stained. The proliferative capability of BMSC to form CFU-F was found to be higher in cardiogel coated plates. A significant difference was observed in the number of stained CFU-F colonies (with more than 50 cells) formed in normal and cardiogel coated plates (Fig. 2A). An overall increase in number of stained CFU-F colonies was observed in higher passage number. With increase in passage number, the difference between the number of colonies within the same passage numbers grown on normal and cardiogel coated plates gradually decreased (data not shown). A difference of $\sim 50 \%$ was observed in cells in Pn 2. About $25 \%$ difference was noticed in Pn 7 and Pn 9. 2-way ANOVA showed statistically significant difference between the mean values of number of CFU-F colonies formed $(P=0.002)$ at different passage numbers (Pn 2, 7, and 9) after allowing for the effects of differences in surfaces (Cardiogel coated and Control). Similarly statistically significant difference between the mean values of number of CFU-F colonies formed $(P=0.011)$ on different surfaces (Cardiogel coated and Control) was greater than that expected, after allowing for the effects of differences in passage numbers (Pn 2, 7, and 9).

\section{Cardiogel protective properties against stress}

Oxidative stress was induced in BMSC grown on control and cardiogel coated plates and the protective effect of cardiogel was assessed by considering the growth and viability of cells, as revealed by MTT assay. An increase in cell survivability and growth was observed in cells grown on cardiogel-coated plates as compared to the cells grown without cardiogel at higher concentrations of $\mathrm{H}_{2} \mathrm{O}_{2}$. 

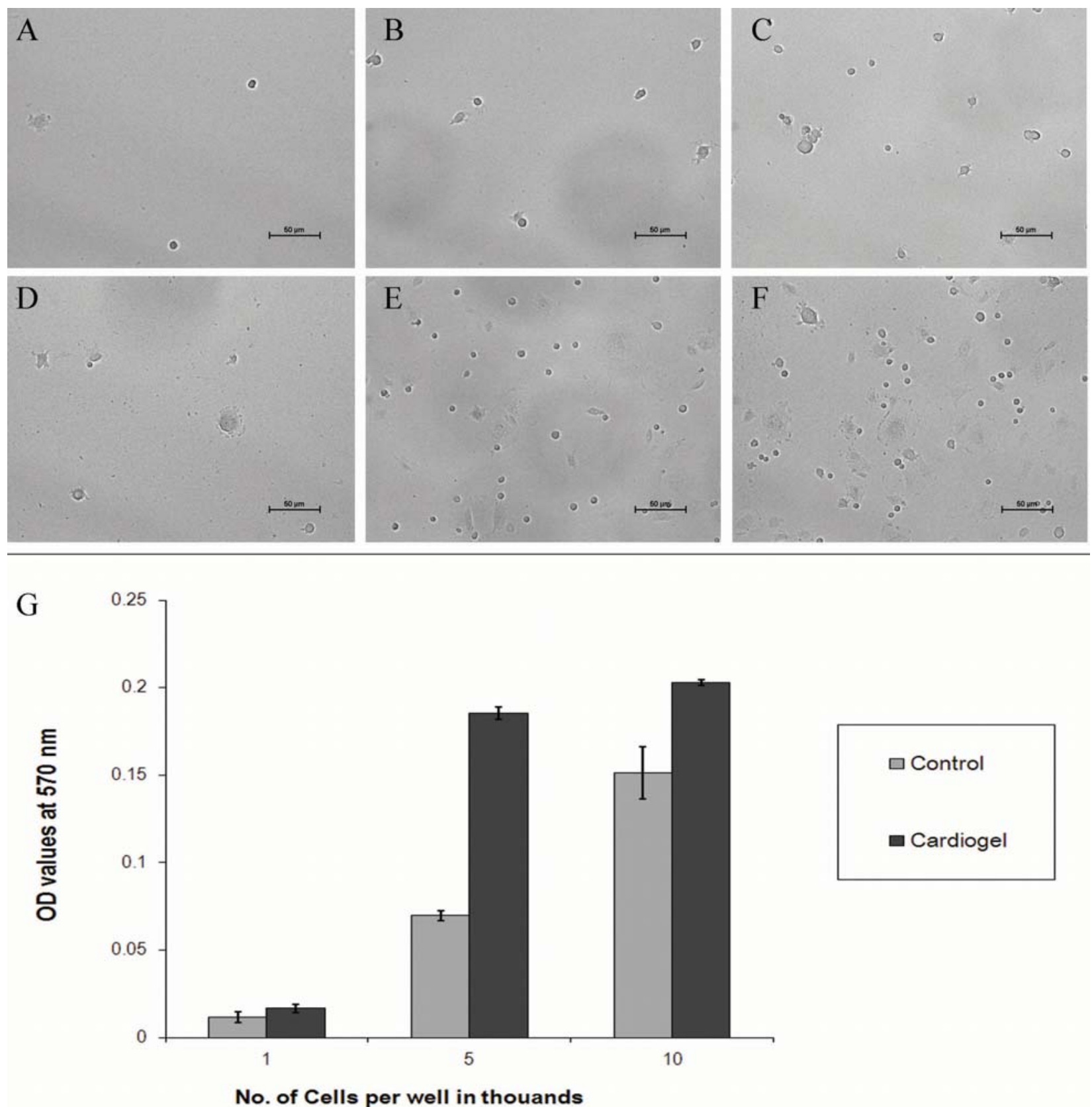

Fig. 4. BMSC adhesion after 1 hour. (a,b,c) Images of BMSC growing on control $(0.2 \%$ Gelatin coated $)$ plate seeded at densities of 1,5 and $10 \times 10^{3}$ cells per well of a 6 well plate showing scale bar of $50 \mu \mathrm{m}$ size; (d,e,f) Images of BMSC growing on cardiogel coated plates seeded at densities of 1,5 and $10 \times 10^{3}$ cells per well of a 6 well plate showing scale bar of $50 \mu \mathrm{m}$ size; (g) Graphical representation of cell viability assay on adherent BMSC growing on control and cardiogel coated plates (after $1 \mathrm{~h}$ of adhesion).

$70 \%$ confluent cells were used in plates exposed to $\mathrm{H}_{2} \mathrm{O}_{2}$ for 1 day to allow the control wells to grow and become confluent. $60 \%$ confluent cells were used in plates exposed to $\mathrm{H}_{2} \mathrm{O}_{2}$ for 4 days to prevent the control wells from overgrowing. This was done to avoid the misinterpretation of cellular activity and even cell death in over grown cells as decrease in cell viability. We standardized the post-plating out time for $60 \%$ and $70 \%$ confluent cells to be used for the stress induction studies as 4 and 2 days respectively.

On exposing BMSC ( $\sim 70 \%$ confluent) for 1 day with $\mathrm{H}_{2} \mathrm{O}_{2}$, less cell death was observed at lower concentrations of $\mathrm{H}_{2} \mathrm{O}_{2}$. It was observed that after exposing cells to $\mathrm{H}_{2} \mathrm{O}_{2}$ concentration between $0.05 \mathrm{mM}$ and $0.5 \mathrm{mM}$, no significant difference was observed in total cell growth, and cell death in both normal and cardiogel-coated. However, at higher concentration $(5 \mathrm{mM})$ the percentage viability of BMSC in normal plates was $\sim 10 \%$ of the viability in untreated plates where as the viability of BMSC in cardiogel-coated plates at similar condition was $\sim 40 \%$ of the viability in untreated plates, which accounted 3 fold higher than in normal plates (Fig. 3A).

Similarly, on exposing BMSC ( $\sim 60 \%$ confluent) for additional time (4 days) with $\mathrm{H}_{2} \mathrm{O}_{2}$, significant cell death was not observed at lower concentrations $(0.05 \mathrm{mM})$ of $\mathrm{H}_{2} \mathrm{O}_{2}$. But at higher concentration $(0.5 \mathrm{mM})$, the percentage 

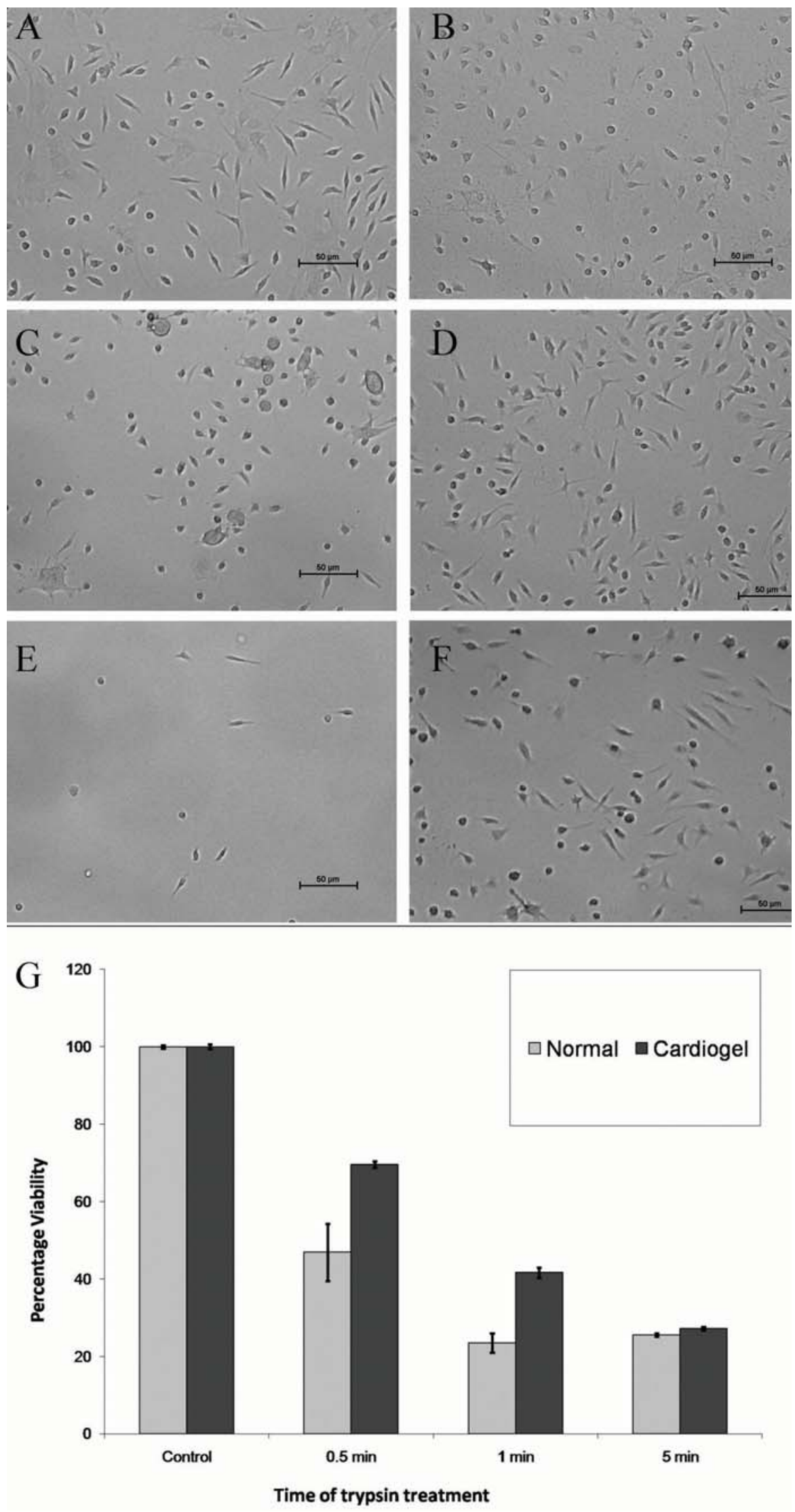

Figure 5. Adhesion studies following enzymatic treatment. (a,b) Images of BMSC growing on control $(0.2 \%$ gelatin coated) and cardiogel coated plate respectively without treatment used as Controls showing scale bar of 50 $\mu \mathrm{m}$ size; (c,e) Images of BMSC growing on control ( $0.2 \%$ gelatin coated) plate after trypsinisation for 30 sec and $1 \mathrm{~min}$ respectively showing scale bar of $50 \mu \mathrm{m}$ size; (d,f) Images of BMSC growing on cardiogel plates after trypsinisation for $30 \mathrm{sec}$ and $1 \mathrm{~min}$ respectively showing scale bar of $50 \mu \mathrm{m}$ size; (g) Graphical representation of cell viability assay of adherent BMSC growing on control and cardiogel coated plates after Trypsin treatment, with percentage viability calculated by considering OD values of both the controls as $100 \%$. 


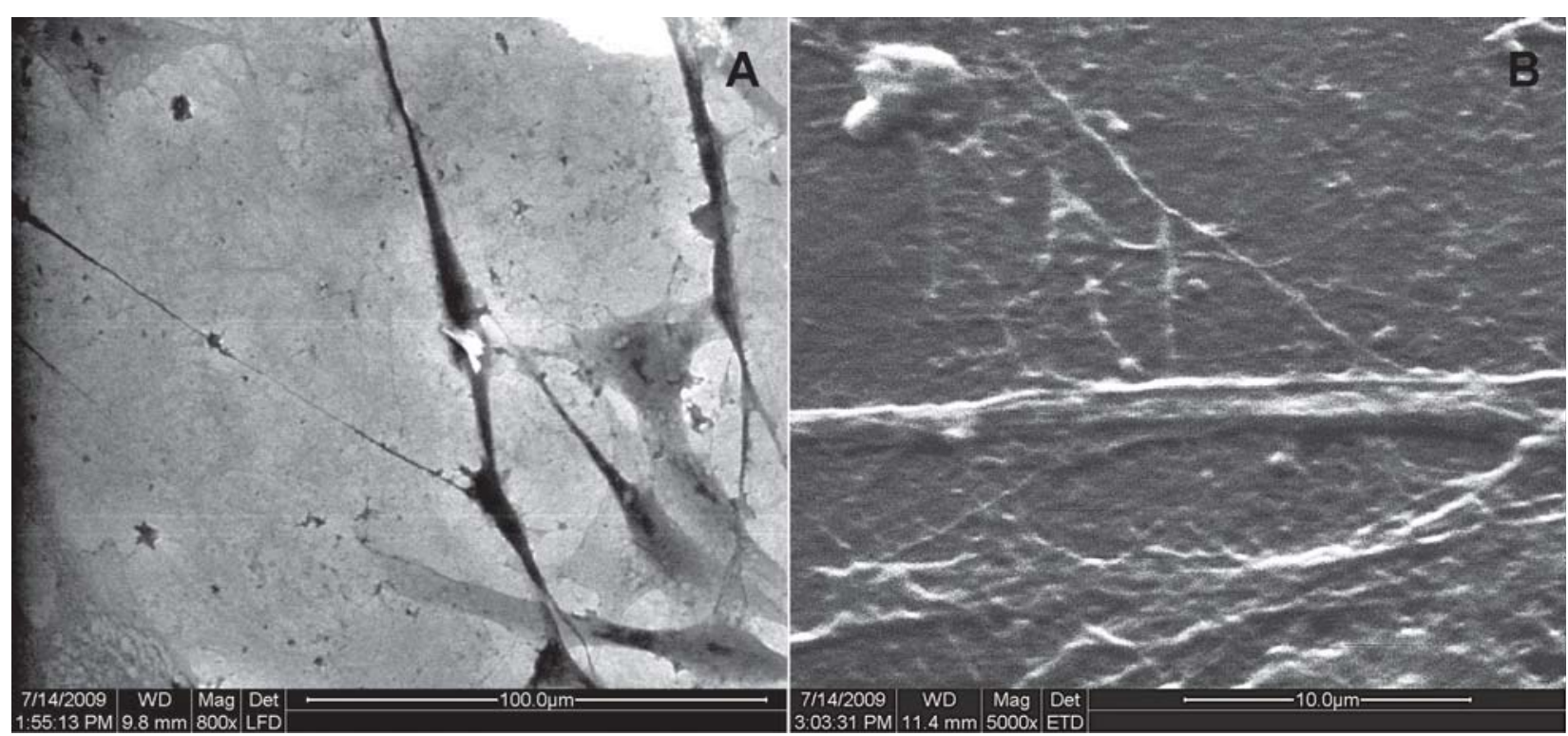

Fig. 6. SEM Images of BMSC grown on cardiogel coated surfaces showing enmeshment. (a) Normal view showing scale bar of $100 \mu \mathrm{m}$ size; (b) Tilted view after gold palladium coating showing scale bar of $10 \mu \mathrm{m}$ size.

of viable BMSC in normal plates was $\sim 70 \%$ as compared to cardiogel-coated plates where cell count was $\sim 80 \%$. This difference in viability increased up to 5 folds at higher $\mathrm{H}_{2} \mathrm{O}_{2}$ concentration (Fig. 3B). Three way analysis of variance (3-way ANOVA) was done with the above data, after the data from $0.05 \mathrm{mM}$ concentration was excluded from analysis. The results showed statistically significant difference between the mean values of number of viable cells $(P=0.026)$ on different days of $\mathrm{H}_{2} \mathrm{O}_{2}$ exposure (1 and 4 days) after allowing for effects of differences in $\mathrm{H}_{2} \mathrm{O}_{2}$ concentrations $(0.05,0.5,5$ and $50 \mathrm{mM})$ and surfaces (Cardiogel coated and Control). Similarly statistically significant difference between the mean values of number of viable cells $(P \leq 0.001)$ at different $\mathrm{H}_{2} \mathrm{O}_{2}$ concentrations $(0.05,0.5,5$ and $50 \mathrm{mM})$ was greater than would be expected after allowing the effects of differences in days of $\mathrm{H}_{2} \mathrm{O}_{2}$ exposure ( 1 and 4 days) and surfaces (Cardiogel coated and Control). Likewise, statistically significant difference between the mean values of number of viable cells $(P=0.047)$ among the different levels of surfaces (Cardiogel coated and Control) was found to be greater than expected after allowing the effects of differences in days of $\mathrm{H}_{2} \mathrm{O}_{2}$ exposure ( 1 and 4 days) and $\mathrm{H}_{2} \mathrm{O}_{2}$ concentrations $(0.05,0.5,5$, and $50 \mathrm{mM})$.

\section{Cell adhesion studies}

To demonstrate the adhesion intensity of cells in to the scaffold, two different assays were performed. For both assays, $0.2 \%$ gelatin coated plates were used as normal (control). Firstly, to determine whether increased cell proliferation on cardiogel was an outcome of cellular attachment to the scaffold, cellular adhesion assays were performed. BMSC seeded at various concentrations onto normal and cardiogel coated plates were allowed to adhere for $1 \mathrm{~h}$ at $37^{\circ} \mathrm{C}$ and the total number of viable adherent cells was then determined by MTT assay. The increased OD during MTT assay in cardiogel coated plates correlated with the higher number of adherent cells, visualized by microscopic observation (Nikon Eclipse Ti) (Fig. 4).

The second adhesiveness assay was performed to examine the intensity of adhesion between the scaffold and the mesenchymal stem cells. The intensity of cellular adhesion, a factor dependent on the cellular components and the molecules present on matrix surface, was correlated to the time required by the cells to disassociate from the surface. $\sim 70 \%$ confluent BMSC grown on normal and cardiogel coated plates were trypsinized for varying time periods to remove the non-adherent cells and the extent of cell adhesion was quantified by MTT assay. A conspicuous difference in development of MTT was observed much similar to that of the previous experiment. The percentage viability was calculated by considering both the controls as $100 \%$. The increased levels of MTT values in cardiogel coated plates correlated with the presence of higher number of adherent cells (Fig. 5).

\section{SEM analysis}

SEM showed the level of attachment of BMSC on cardiogel. The cells were found to be enmeshed in cardiogel (Fig. 6A) and the cellular appendages were found to penetrate in to the cardiogel (Fig. 6B).

\section{Discussion}

In the present study, we elucidated the growth characteristics of bone marrow derived stem cell in cardiogel. Our study demonstrated that BMSC were able to survive, proliferate and adhere better in presence of cardiogel than in normal environment during conditions of stress. Comparative cell proliferation assay studies on normal and cardiogel-coated plates confirmed an increased cell growth. This could be attributed to augmented cell attachment to the scaffold. The results obtained from the 
modified $1 \mathrm{~h}$ adhesion assay evidently demonstrated an increased cellular adhesion within a short time period in cardiogel coated plates when compared to normal growth condition (Lapi et al., 2008; Vohra et al., 2008) (Fig. 4). An alternate explanation for the increased cell growth in cardiogel could be the combinatorial effect of numerous extracellular matrix components and signals in cardiogel that would have stimulated faster cell division (Perkins and Fleischman, 1990; VanWinkle et al., 1996). However, FACS analysis could not be performed to validate any of the above data sets as the cells were tightly bound to the scaffold and hence couldnot be disloged readily from cardiogel. The adhesion assay using trypsinisation clearly shows that $\sim 40 \%$ of cardiogel adherent cells could be disloged even after exposure to $0.25 \%$ trypsin for $1 \mathrm{~min}$. Scraping of the cells for analysis could not be performed since the scaffold tended to dislodge along with the cells and enmesh around them. Hence it was not feasable to perform FACS analysis. This unique property shown by cardiogel of having a strong cellular adhesion to BMSC in a short time period could be useful in tissue engineering applications especially in case of delivery of stem cells in to injured tissue. Injured tissue can be patched with cardiogel, which can then allow the binding of stem cells delivered directly to the site or intra venously and since only a short time period is required, flow off of the delivered stem cells to redundant sites can be prevented. This property also corroborates the previously described usages of stem cell-seeded scaffold as an alternative therapeutic modality for medically intractable advanced heart failure (Piao et al., 2007). The therapeutic applications of cardiogel using stem cells has not been reported, however many other scaffolds have been used in conjunction with stem cells ( Christman and Lee, 2006; Chen et al., 2008).

As reported earlier, cardiogel can help in differentiation of embryonic stem cells into functional cardiomyocytes (Baharvand et al., 2005). The CFU-F assay results showed an augmentation of CFU-F colonies when cultured on cardiogel due to increase in cell differentiation. It was observed in the present study that the number of CFU-F colonies formed was much higher with increasing passage number. This increase in CFU-F colonies contradicted with data obtained from previous reports (Perkins and Fleischman, 1990). After a few passages of marrow cells, the predominant population was of CFU-F origin, which in turn added up to the existing population (Fig. 2A). It has been already established that stromal cell progeny of murine bone marrow fibroblast colony-forming units are clonal endothelial-like cells, that express collagen IV and laminin (Perkins and Fleischman, 1990). Production of adhesion molecules by the cells and their progeny could have led to rapid proliferation of CFU-F cells. However, this could be also due to the usage of nutrient rich medium containing $20 \%$ FCS for culture in the present study which would have resulted in the rapid expansion of CFU-F precursors (Biagioli et al., 2000).

A significant observation was made about the ability of cardiogel to protect BMSC from stress. In the present study, we used $\mathrm{H}_{2} \mathrm{O}_{2}$ to induce oxidative stress to BMSC.
Ischemia induces oxidative stress in tissues through accumulation of toxic substances especially due to free radicals (Chen et al., 2000; Chang et al., 2006). Stress induction using $\mathrm{H}_{2} \mathrm{O}_{2}$ exposure in vitro generates an ischemia like condition much similar to that in vivo (Song et al., 2010). This condition was used by us to show the protection offered by cardiogel. As compared to short term exposure (1-5 min) of $\mathrm{H}_{2} \mathrm{O}_{2}$ on BMSCs, better protection results were observed in long term exposure (1-4 days). It is known that short term exposure with low-dose $\mathrm{H}_{2} \mathrm{O}_{2}$ increases VEGF expression and enhances the survival and efficacy of BMSC for neovascularization and thus can be used in therapeutic angiogenesis (Kubo et al., 2007). Nevertheless, higher doses and long term exposure of $\mathrm{H}_{2} \mathrm{O}_{2}$ increases cellular reactive oxygen species level, which ultimately leads to cell death. However, in our study significant reduction in cell death was observed, when BMSC were grown on cardiogel. This could be attributed to the presence of extra-cellular matrix components, which provides sites for cellular binding and may also contain growth factors (VanWinkle et al., 1996). The 3dimensional architecture of the scaffold may also influence the growth of BMSC in presence of $\mathrm{H}_{2} \mathrm{O}_{2}$ (Davis et al., 2006).

To summarize, our study demonstrated an increase in cell proliferation and differentiation when BMSC were grown on cardiogel. BMSC growing on cardiogel also showed better oxidative stress tolerance induced by $\mathrm{H}_{2} \mathrm{O}_{2}$. Adhesion of BMSC to the scaffold occurred at a faster rate when compared to control. Cells once adherent showed increased resistance to dislodgment even by trypsinisation as clearly indicated in adhesion studies. Previous reports had suggested the use of a biodegradable scaffold along with which, cells can be injected to the site of ischemia. The present study clearly demonstrated that BMSC once grown or allowed to adhere with cardiogel showed strong binding affinity with scaffold. The cells proliferated, differentiated and even withstood the artificial oxidative stress. This when compared to other biomaterial scaffolds including commercially available ones like Matrigel (BD Biosciences, Franklin Lakes, NJ, USA) could either deliver cells or promote in situ regeneration (Kutschka et al., 2006; Laflamme et al., 2007). The long-term effects including immunogenic response of such materials are yet to be completely understood. With this study, we have demonstrated that cardiogel is an efficient potentially biodegradable three-dimensional extracellular matrix and could be used for engineering cardiac tissue structures for cell culture and potential therapeutic applications post ischemic cardiac tissue regeneration. Further work with animal models will confirm the applicability of this biomaterial for therapeutic purposes.

\section{Acknowledgments}

This work was supported by grants to RSV by the Department of Biotechnology, Govt. of India (BT/PR7951/ MED/14/1193/2006) and by fellowship to SP by the Indian Council for Medical Research (No. 3/1/3/JRF/37/MPD/ 2004(32402)). 


\section{References}

Abbate A, Biondi-Zoccai GGL, Van Tassell BW, Baldi A (2009) Cellular preservation therapy in acute myocardial infarction. Am J Physiol Heart Circ Physiol 296: H563565.

Angelos MG, Kutala VK, Torres CA, He G, Stoner JD, Mohammad M, Kuppusamy P (2006) Hypoxic reperfusion of the ischemic heart and oxygen radical generation. Am J Physiol Heart Circ Physiol 290: H341-347.

Baharvand H, Azarnia M, Parivar K, Ashtiani SK (2005) The effect of extracellular matrix on embryonic stem cell-derived cardiomyocytes. J Mol Cell Cardiol 38: 495-503.

Beqqali A, van Eldik W, Mummery C, Passier R (2009) Human stem cells as a model for cardiac differentiation and disease. Cell Mol Life Sci 66: 800-813.

Bettiol E, Clement S, Krause KH, Jaconi ME (2007) Embryonic and adult stem cell-derived cardiomyocytes: Lessons from in vitro models. Rev Physiol Biochem Pharmacol 157: 1-30.

Biagioli B, Maccherini M, Carlucci F, Tabucchi A, Matucci R, Mugelli A (2000) Oxidative stress: Clinical implications in cardiac surgery. Ital Heart J 1: S43-S45.

Bick RJ, Snuggs MB, Poindexter BJ, Buja LM, Van Winkle WB (1998) Physical, contractile and calcium handling properties of neonatal cardiac myocytes cultured on different matrices. Cell Comm Adhes 6: 301-310.

Catharina N, Nan M, Karen B, Wolfgang W, Anthony H, Yrjö TK, Hao Z, Mihail EH, Gustav S (2008) Mesenchymal stem cells and cardiac repair. J Cell Mol Med 12: 1795-1810.

Chang W, Kim J-Y, Lim S, Lee S, Song B-W, Kim HJ, Cha M-J, Kwon S-Y, Han S-M, Min B-H, Jang Y, Chung N, Hwang K-C (2006) Mesenchymal stem cells with calreticulin gene modulate cell adhesiveness through an integrin-mediated mechanism. Tissue Eng Regen Med 3: 327-335.

Chang W, Lim S, Song H, Lee S, Song B-W, Jang Y, Chung N, Hwang K-C (2007) In vitro expansion of mesenchymal stem cells using 3-D matrix derived from cardiac fibroblast. Tissue Eng Regen Med 4: 370-375.

Chen QM, Tu VC, Wu Y, Bahl JJ (2000) Hydrogen peroxide dose dependent induction of cell death or hypertrophy in cardiomyocytes. Arch Biochem Biophys 373: 242-248.

Chen Q-Z, Harding SE, Ali NN, Lyon AR, Boccaccini AR (2008) Biomaterials in cardiac tissue engineering: ten years of research survey. Mater Sci Eng R Rep 59: 1-37.

Christman KL, Lee RJ (2006) Biomaterials for the treatment of myocardial infarction. J Am Coll Cardiol. 48: 907-913.

Costanzo MR, Augustine S, Bourge R, Bristow M, O'Connell JB, Driscoll D, Rose E (1995) Selection and treatment of candidates for heart transplantation: A statement for health professionals from the committee on heart failure and cardiac transplantation of the council on clinical cardiology, American Heart Association. Circulation 92: 3593-3612.
Davis RA, Van Winkle WB, Buja LM, Poindexter BJ, Bick RJ (2006) Effect of a simple versus a complex matrix on the polarity of cardiomyocytes in culture. J Burns Wounds 5: 16-25.

Dimarakis I, Habib NA, Gordon MYA (2005) Adult bone marrow-derived stem cells and the injured heart: Just the beginning? Eur J Cardiothorac Surg 28: 665-676.

Dimarakis I, Levicar N, Nihoyannopoulos P, Gordon MY, Habib NA (2006a) In vitro stem cell differentiation into cardiomyocytes: Part 2: Chemicals, extracellular matrix, physical stimuli and coculture assays. J Cardiothorac Renal Res 1: 115-121.

Dimarakis I, Levicar N, Nihoyannopoulos P, Habib NA, Gordon MY (2006b) In vitro sem cell differentiation into cardiomyocytes: Part 1. Culture medium and growth factors. J Cardiothorac Renal Res 1: 107-114.

Donald GP, Darwin JP (2007) Concise review: Mesenchymal stem/multipotent stromal cells: The state of transdifferentiation and modes of tissue repair - current views. Stem Cells 25: 2896-2902.

Heng BC, Haider HK, Sim EK-W, Cao T, Ng SC (2004) Strategies for directing the differentiation of stem cells into the cardiomyogenic lineage in vitro. Cardiovasc Res 62: 34-42.

Inaba K, Inaba M, Romani N, Aya H, Deguchi M, Ikehara S, Muramatsu S, Steinman RM (1992) Generation of large numbers of dendritic cells from mouse bone marrow cultures supplemented with granulocyte/ macrophage Colony-Stimulating Factor. J Exp Med 176: 1693-1702.

Ishii O, Shin M, Sueda T, Vacanti JP (2005) In vitro tissue engineering of a cardiac graft using a degradable scaffold with an extracellular matrix-like topography. J Thorac Cardiovasc Surg 130: 1358-1363.

Jon SO, Dan SK, James AT (2001) Multilineage differentiation from human embryonic stem cell lines. Stem Cells 19: 193-204.

Kraehenbuehl TP, Zammaretti P, Van der Vlies AJ, Schoenmakers RG, Lutolf MP, Jaconi ME, Hubbell JA (2008) Three-dimensional extracellular matrix-directed cardioprogenitor differentiation: Systematic modulation of a synthetic cell-responsive peg-hydrogel. Biomaterials 29: 2757-2766.

Kubo M, Li T-S, Suzuki R, Ohshima M, Qin S-L, Hamano K (2007) Short-term pretreatment with low-dose hydrogen peroxide enhances the efficacy of bone marrow cells for therapeutic angiogenesis. Am J Physiol Heart Circ Physiol 292: H2582-2588.

Kutschka I, Chen IY, Kofidis T, Arai T, von Degenfeld G, Sheikh AY, Hendry SL, Pearl J, Hoyt G, Sista R, Yang PC, Blau HM, Gambhir SS, Robbins RC (2006) Collagen matrices enhance survival of transplanted cardiomyoblasts and contribute to functional improvement of ischemic rat hearts. Circulation 114: I-167-173.

Laflamme MA, Chen KY, Naumova AV, Muskheli V, Fugate JA, Dupras SK, Reinecke H, Xu C, Hassanipour M, Police S, O’Sullivan C, Collins L, Chen Y, Minami E, Gill EA, Ueno S, Yuan C, Gold J, Murry CE (2007) Cardiomyocytes derived from human embryonic stem cells 
in pro-survival factors enhance function of infarcted rat hearts. Nat Biotechnol 25: 1015-1024.

Lapi S, Nocchi F, Lamanna R, Passeri S, Iorio M, Paolicchi A, Urciuoli P, Coli A, Abramo F, Miragliotta V, Giannessi E, Stornelli M, Vanacore R, Stampacchia G, Pisani G, Borghetti L, Scatena F (2008) Different media and supplements modulate the clonogenic and expansion properties of rabbit bone marrow mesenchymal stem cells. BMC Res Notes 1: 53.

Memon IA, Sawa Y, Fukushima N, Matsumiya G, Miyagawa S, Taketani S, Sakakida SK, Kondoh H, Aleshin AN, Shimizu T, Okano T, Matsuda H (2005) Repair of impaired myocardium by means of implantation of engineered autologous myoblast sheets. J Thorac Cardiovasc Surg 130: 1333-1341.

Orlic D, Hill JM, Arai AE (2002) Stem cells for myocardial regeneration. Circ Res 91: 1092-1102.

Perkins S, Fleischman RA (1990) Stromal cell progeny of murine bone marrow fibroblast colony-forming units are clonal endothelial-like cells that express collagen IV and laminin. Blood 75: 620-625.

Piao H, Kwon J-S, Piao S, Sohn J-H, Lee Y-S, Bae JW, Hwang K-K, Kim D-W, Jeon O, Kim B-S, Park Y-B, Cho M-C (2007) Effects of cardiac patches engineered with bone marrow-derived mononuclear cells and PGCL scaffolds in a rat myocardial infarction model. Biomaterials 28: 641-649.

Reffelmann T, Kloner RA (2003) Cellular cardiomyoplasty - Cardiomyocytes, skeletal myoblasts, or stem cells for regenerating myocardium and treatment of heart failure? Cardiovasc Res 58: 358-368.

Song H, Chang W, Lim S, Seo H-S, Shim CY, Park S, Yoo K-J, Kim B-S, Min B-H, Lee H, Jang Y, Chung N, Hwang K-C (2007) Tissue transglutaminase is essential for integrin-mediated survival of bone marrow-derived mesenchymal stem cells. Stem Cells 25: 1431-1438.

Song H, Cha M-J, Song B-W, Kim I-K, Chang W, Lim S, Choi E, Ham O, Lee S-Y, Chung N, Jang Y, Hwang KC (2010) Reactive oxygen species inhibit adhesion of mesenchymal stem cells implanted into ischemic myocardium via interference of focal adhesion complex. Stem Cells 28: 555-563.

Sreejit P, Kumar S, Verma RS (2008) An improved protocol for primary culture of cardiomyocyte from neonatal mice. In Vitro Cell Dev Biol Anim 44: 45-50.

Struthers AD (2005) Pathophysiology of heart failure following myocardialinfarction. Heart 91: 14-16.

Tang YL, Phillips MI (2007) Invited commentary. Ann Thorac Surg 83: 1499-1500.

Van Laake LW, Hassink R, Doevendans PA, Mummery C (2006) Heart repair and stem cells. J Physiol 577: 467478.

Van Laake LW, Passier R, Doevendans PA, Mummery CL (2008) Human embryonic stem cell-derived cardiomyocytes and cardiac repair in rodents. Circ Res 102: $1008-1010$.

VanWinkle WB, Snuggs MB, Buja LM (1996) Cardiogel: A biosynthetic extracellular matrix for cardiomyocyte culture. In Vitro Cell Dev Biol Anim 32: 478-485.
Vohra S, Hennessy K, Sawyer A, Zhuo Y, Bellis S (2008) Comparison of mesenchymal stem cell and osteosarcoma cell adhesion to hydroxyapatite. J Mater Sci Mater Med 19: 3567-3574.

Wang J-S, Shum-Tim D, Chedrawy E, Chiu RCJ (2001) The coronary delivery of marrow stromal cells for myocardial regeneration: Pathophysiologic and therapeutic implications. J Thorac Cardiovasc Surg 122: 699-705.

Zhu W-Z, Hauch KD, Xu C, Laflamme MA (2009) Human embryonic stem cells and cardiac repair. Transplant Rev (Orlando) 23: 53-68.

\section{Discussion with Reviewers}

Reviewer I: Is it known which specific ECM components influence growth characteristics? If so, please describe!

Authors: Till date the ECM components present in Cardiogel have not been completely characterized. We are attempting to characterize those components, in order to determine the specific components which influence growth and differentiation characteristics.

Reviewer I: The description of the presence of cells with other morphologies indicates a mixed preparation - this is to be expected with such a culture though. Is it known what happens to these cells: do they dedifferentiate, take on stem cell characteristics, die, etc.? Although immunocytochemical analysis demonstrates that cells are generally stem cells, it would be of interest to know what happens to these other cells.

Authors: We always obtained cells with other morphologies clearly indicating a mixed culture during the initial passages. Most of these cells are macrophages, dendritic cells or other non stem cell populations found in the bone marrow. Almost all these cells are highly differentiated except for the progenitor cells of the above populations and do not have the capacity to attain stem cell characteristics, unless newer technologies like iPS are used. Since these cells are mostly terminally differentiated, these cells cannot be maintained for more than 2-4 passages unless specific growth factors are added to allow the proliferation of the progenitor cells. (Inaba et al., 1992, text reference).

Reviewer I: Regarding your stress data description: $\mathrm{H}_{2} \mathrm{O}_{2}$ exposure can lead to apoptosis. It would be of interest to see whether the described protection against $\mathrm{H}_{2} \mathrm{O}_{2}$-induced stress by cardiogel is due to less apoptosis - it is recommended that the authors compare $\mathrm{H}_{2} \mathrm{O}_{2}$-induced apoptosis (e.g., DNA laddering, TUNEL assay, caspase activation, etc.) in cells plated out on gelatin and cardiogel coated plates - additional controls could include comparing effects to other scaffolds such as Matrigel - that would indicate whether protective effects are due specifically to cardiogel, or if they are as a result of general 3D culture conditions.

Authors: We agree with the point that the reviewer has raised about the apoptosis of cells due to $\mathrm{H}_{2} \mathrm{O}_{2}$ exposure. The data of these experiments will surely point out the 
mechanism of protection provided by cardiogel. But along with these experiments, other molecular studies and assays needs to be done to elucidate the mechanism of cell proliferation and adhesion in cardiogel, to give the complete picture of how the BMSC binds to the cardiogel and how it is protected against stress. Besides oxidative stress, other stress like mitochondrial stress and hypoxia has to be also compared. We are already working in this direction.

Reviewer I: Why was the ' $0.05 \mathrm{mM}$ ' data excluded from the analysis?

Authors: The $0.05 \mathrm{mM}$ data has been excluded from the analysis since the data was considered as an outlier through statistical analysis. Secondly, previous studies with low dose exposure of $\mathrm{H}_{2} \mathrm{O}_{2}$ have been shown to increase BMSC proliferation. However high dose exposure of $\mathrm{H}_{2} \mathrm{O}_{2}$ clearly show a decrease in cell viability which occurs due to stress induced by $\mathrm{H}_{2} \mathrm{O}_{2}$ exposure. Since this assay was done to compare the protection capability of cardiogel coated and control plates to MBMC against oxidative stress induced through $\mathrm{H}_{2} \mathrm{O}_{2}$ exposure, therefore the data points above the controls were not considered for statistical analysis. However high dose exposure of $\mathrm{H}_{2} \mathrm{O}_{2}$ clearly show a decrease in cell viability which occurs due to stress induced by $\mathrm{H}_{2} \mathrm{O}_{2}$ exposure. Since this assay was done to compare the protection capability of cardiogel coated and control plates to MBMC against oxidative stress induced through $\mathrm{H}_{2} \mathrm{O}_{2}$ exposure, therefore the data points above the controls were not considered for statistical analysis.

Reviewer I: Why is the BrdU labeling data not given? This would be a better measure of proliferation than MTT data; MTT measures the relative number of metabolically active cells (this also encompasses cell death), whereas BrdU directly measures cells showing DNA synthesis, e.g., actively dividing. It is recommended that $\mathrm{BrdU}$ data is given; both micrographs and cell count data (number of BrdU positive cells/total cells - if it is not possible to do this by FACS analysis, then cell counts of immunofluorescently labeled cells may be employed - see Edwards et al. (2008) for method and analysis details.

Authors: Our study shows that cells were tightly bound to the scaffold and hence could not be dislodged readily from cardiogel. As a result BrdU labeling studies could not be performed since FACS analysis needs cellular dislodgement and prolonged trypsinisation to dislodge the cells may show erroneous results. We also accept the point raised by the reviewer that BrdU labeling is a better measure of proliferation than MTT, since BrdU directly measures cells showing DNA synthesis. An attempt was made to replicate the methodology suggested by the reviewer, but non-specific staining of scaffold with Anti anti BrdU antibody in the background makes cell counting through BrdU labeling a challenge.

Reviewer I: Serum in the media can influence cell proliferation, protection against oxidative stress, etc. It would be of interest to see how the cells proliferate, differentiate and respond to oxidative stress on control and cardiogel surfaces with lower serum concentrations or in the absence of serum.

Authors: We agree that it would be quite interesting to study the influence of serum on cell proliferation, differentiation and response to oxidative stress on control and cardiogel surfaces. Since our aim to replicate the in vivo condition in vitro where the tissue is constantly supplied by fluids like blood or lymph, this does not fall under the main aim of the study.

Reviewer I: Is it known what the lifetime of $\mathrm{H}_{2} \mathrm{O}_{2}$ in culture is; it may become expended rapidly. Were cells exposed to a single dose or, in experiments where cells were treated for 1-4 days, were the media containing $\mathrm{H}_{2} \mathrm{O}_{2}$ replaced with fresh media containing $\mathrm{H}_{2} \mathrm{O}_{2}$ periodically?

Authors: The lifetime of $\mathrm{H}_{2} \mathrm{O}_{2}$ in culture is not known and it may be expended rapidly. However our data as shown in Fig. 3A and 3B proves that, even after prolonged treatment for 4 days, $\mathrm{H}_{2} \mathrm{O}_{2}$ in final concentrations of 0.5 and $5 \mathrm{mM}$ were able to induce more stress compared to that treated for 1 day. In our studies, the cells were exposed to only a single dose, even when cells were treated for 14 days and the media containing $\mathrm{H}_{2} \mathrm{O}_{2}$ was not at all replaced with fresh media containing $\mathrm{H}_{2} \mathrm{O}_{2}$ periodically.

Reviewer I: A reduction in cell death may also be due to the cardiogel/ECM or serum in the medium quenching reactive oxygen species?

Authors: We agree with the reviewer that reduction in cell death may also be due to the cardiogel/ECM quenching reactive oxygen species. However the point that serum in the medium may quench reactive oxygen species is debatable since, significant difference in cell viability was observed between cells grown on cardiogel coated and control plates. Besides prolonged $\mathrm{H}_{2} \mathrm{O}_{2}$ treatment (final concentrations of 0.5 and $5 \mathrm{mM}$ ) for 4 days were able to induce more stress compared to that treated for 1 day. Thus it is quite unlikely that serum may quench reactive oxygen species and thus influence cell viability.

Reviewer II: Although the authors tested the effects of oxidative stress on marrow stromal cells grown on cardiogel, it is not clear how this mimics a clinical scenario. By the time such an implantation may occur in a host this oxidative stress related condition may not prevail.

Authors: Stem cell transplantation in cardiac therapy by means of the direct injection method is subject to the loss of intercellular communication, extracellular matrix, and cell numbers. Implantation of stem cell sheets might be more advantageous in repairing the impaired heart by providing uniform and stable cell delivery with less cell loss and without disrupting the cell-cell microenvironment (Memon et al., 2005, text reference). Bioengineered cardiac grafts have been created previously by combining autologous cell transplantation with a degradable scaffold as a temporary extracellular matrix (Ishii et al., 2005, text reference). Recently, two studies from different groups have reported on successful engraftment of cardiomyocytes is enhanced by co-delivery of the cells with matrix. Kutschka and co-workers have demonstrated that grafts 
were larger and ventricular function was improved in infarcted rat hearts, when human ESC-derived cardiomyocytes were delivered together with collagen matrices, including Gel Foam and the basement membrane preparation, Matrigel (Kutschka et al., 2006, text reference). Matrigel was found to significantly enhance survival of hESC-derived cardiomyocytes in infarcted rat hearts (Laflamme et al., 2007, text reference). Reactive oxygen species (ROS), a major cause of injury after ischemia/reperfusion, may hinder the adhesion and spreading of MSCs. Generation of ROS is dramatically increased over three-fold in the risk region in ischemia/ reperfusion-injured animal hearts compared to wild-type animal hearts (Song et al., 2010, text reference). Tissue hypoxia mediates an increase in the ROS burst at reperfusion and is associated with further impairment of LV functional recovery. The greatest increase in ROS formation was noted in the most hypoxic myocardial tissue at the time of reperfusion (Angelos et al., 2006, text reference). Our study was directed to assess the survival and proliferation potential of stem cells grown on cardiogel as cell support sheets and also to assess tolerance to oxidative stress in vitro.

We accept the point raised by the reviewer that by the time such an implantation may occur in a host this oxidative stress related condition may not prevail. However the recurrence of cardiac infarction and increase in size of ischemic area remains a possibility due to the continued presence of diseased coronary arteries. The repair to the heart muscle is not always complete and scarring is usually present. There is also the risk of heart failure developing over a period of weeks as the heart reacts to the injury it has sustained. For these reasons it is necessary for patients to be monitored carefully and to receive the appropriate treatment to reduce the risk of further disease progression and other heart attacks. Medical treatment is aimed at preventing further damage and the chance of repeat heart attacks in the future by opening the blocked artery and restoring the blood flow to the affected area of heart muscle by reperfusion. However reperfusion as previously said increases a three-fold generation of ROS.

Reviewer II: The authors demonstrated that stromal cells cultured on cardiogel are more adherent than cells cultured on control plates. The authors discussed about the possible applications of cardiogel as a scaffold to grow or differentiate cardiomyocytes from other cell sources but did not discuss how such cardiogel containing grown cells would be removed intact and implanted since they are very adherent. Others have shown that oxidative stress diminishes the adhesiveness of stromal cells on cardiogel (Song et al., 2010, text reference), this need to be discussed in this context. Also, could you describe the status of stromal cells following $\mathrm{H}_{2} \mathrm{O}_{2}$ treatment?

Authors: The reviewer has raised a valid question regarding the removal and implantation of cardiogel containing grown cells. Cardiogel by nature is adherent and would be difficult to remove. However, during our studies we have found that cardiogel tends to get dislodged from surface by altering the $\mathrm{pH}$ of the solution. Another option is by using scrapers to remove a portion and to peel off the remaining portion, but this is effective for thicker and larger gels. After the dislodgment, the cardiogel with cells can be directly implanted at the site of injury. In case of delivery through injection, the cardiogel with cells may be completely scrapped even without altering the $\mathrm{pH}$ of media. It is however advisable to use the implantation method to avoid the loss of intercellular communication, extracellular matrix, and cell numbers.

Song et al. (2010, text reference) did demonstrate that oxidative stress diminished the adhesiveness of stromal cells on cardiogel. But the authors also pointed out that the cell adhesions to fibronectin-coated plates and the cardiogel were significantly increased as compared with adhesion to bare plates. Only $\mathrm{H}_{2} \mathrm{O}_{2}$ treatment significantly reduced the amount of adhered MSCs at the indicated times, regardless of the coating material. Our data corroborate well with the above findings that cell adhesions to the cardiogel coated plates were significantly increased as compared with adhesion to bare plates and also that $\mathrm{H}_{2} \mathrm{O}_{2}$ treatment significantly reduced the amount of adherent cells.

Reviewer II: An explanation regarding why a certain passage number of marrow stromal cells was chosen would be helpful. The authors describe increase cell survivability of cells cultured on cardiogel rather than reduced survival of the cells in control culture.

Authors: Most of the previous reports have used BMSC within the 15 passages of initial plating. At latter passages due to increase in spontaneous differentiation and increased proliferation of differentiated cells, there is a net decrease in number of BMSC. Therefore, we have used BMSC below passage number 15 for our studies. Our study was directed towards utilizing cardiogel as a therapeutic scaffold. Therefore, we were interested in determining the increase in survivability of cells grown on cardiogel and its comparison with cells grown on control plates.

Reviewer II: What is the mechanism of protection from oxidative stress in bone marrow stromal cells cultured on cardiogel and why does this protection diminish with time? Authors: The mechanism of protection from oxidative stress in bone marrow stromal cells cultured on cardiogel has not been completely elucidated. We suspect that the reduction in cell death may be due to the ROS quenching by cardiogel/ECM. However, it should be also noted that the medium or its constituents may likely quench ROS is debatable. Significant difference in cell viability was also observed between cells grown on cardiogel coated and control plates. Prolonged $\mathrm{H}_{2} \mathrm{O}_{2}$ treatment (final concentrations of 0.5 and $5 \mathrm{mM}$ ) for 4 days was able to induce more stress compared to that treated for 1 day. Thus it is quite unlikely that media may quench ROS and thus influence cell viability. Therefore the only parameter which may quench the ROS in the experiment is the cardiogel/ ECM. Similarly, by using N-acetyl L-cysteine (free radical scavenger) (Song et al., 2010, text reference) for cotreatment in $\mathrm{H}_{2} \mathrm{O}_{2}$ treated MSCs, adhesion and spreading inhibition was reduced and detachment from surface 
decreased. Therefore the reduction in cell death might be due to the cardiogel/ECM quenching ROS. Further studies are required to prove this observation.

The diminished protection, which arose with time may be due to the decreased quenching of ROS by cardiogel/ ECM over the treatment period. Another possibility is due to the activation of alternative pathways by the scavenging ROS on long-term exposure.

\section{Additional Reference}

Edwards GO, Jondhale S, Chen T, Chipman JK (2008) A quantitative inverse relationship between connexin32 expression and cell proliferation in a rat hepatoma cell line. Toxicology 253: 46-52. 